\title{
Challenges Affecting the Teaching and Learning of Integrated Science in Rural Junior High Schools in Ghana
}

\author{
Rebecca Esi Quansah*, Nelly Adjoa Sakyi-Hagan, Charles Essiam \\ Department of Integrated Science Education, University of Education, Winneba, Ghana
}

*Corresponding Author: esibeckles@yahoo.co.uk

\section{ABSTRACT}

The study investigated challenges affecting the teaching and learning of Integrated Science in rural Junior High Schools (JHSs) in the Effutu Municipality in the central region of Ghana. A qualitative approach was employed. Purposive sampling was employed to select six rural JHSs from the municipality. A closed-structured interview was used to collect data from head teachers, teachers, and pupils, and then analyzed. The study revealed that inadequate instructional materials and poor proficiency of pupils in the English language affected the teaching and learning of Integrated Science. The study concluded that if these challenges were addressed, teaching and learning of Integrated Science would be improved in rural JHSs. It is recommended that Integrated Science teachers should be trained to improvise instructional material using materials in the environment to teach the subject. This would help pupils to conceptualize scientific concepts as they interact with the materials. Again, pupils should be encouraged to build their English vocabulary to express and make informed contributions to the teaching and learning of integrated science.

KEY WORDS: integrated science; rural; Junior High Schools; instructional materials; medium of instruction

\section{INTRODUCTION}

B asic education in Ghana comprises a 2-year kindergarten, 6-year primary, and 3-year Junior High School (JHSs) (MoE, 2004). It is the minimum formal education every child is entitled to for them to be equipped with the essential knowledge and skills that will make them interact meaningfully with their society. To adapt and function successfully in society, every individual requires general scientific literacy to enable him/her to make informed choices and decisions at every turn in a world of science and technology. That is why Ghana subscribes to the goal "science for all" (MoE, 2010). In deference of this goal, the government of Ghana has made teaching and learning of science a core subject in basic education across the country from Primary Year Four (students aged 9 years old) through to JHS Year 3 (students aged 14 years old).

For citizens to understand basic scientific concepts and to function appropriately in their environment demands quality teaching and learning of Integrated Science from primary four through to JHS three. The teaching and learning of Integrated Science comprise physics, chemistry, biology, and agricultural science. Many researchers have identified the quality of science teaching and learning could be affected by many factors including content knowledge and pedagogical skills of the teacher due to poor teacher preparation, inadequate, and inappropriate instructional materials, medium of instruction, lack of effective supervision and monitoring at school, lack of motivation for teachers, and inadequate number of qualified teachers to fill empty classrooms, poor attitude, and interest of pupils among others (Anamuah-Mensah et al., 2017; Fredua-Kwarteng \& Ahia, 2005; Ngman-wara 2015; Parker, 2004; Hill et al., 2005). However, the use of English language as a medium of instruction and inadequate instructional resources has been reported as important challenge to science teaching and learning in Ghanaian schools as observed by the researchers. This is because students have to comprehend scientific concepts taught and engage in hands-on activities, critical thinking, and problem-solving in the teaching and learning of the subject. Ghana is a multilingual country with English, a colonial legacy as the official language for its citizen. English language is the medium of instruction for teaching and learning all subjects including Integrated Science from Primary Four in the school system (MoESS, 2007). This means that success in education at all levels depends, to a very large extent, on the individual's proficiency in the English language (MoESS, 2007). The use of the English language could unintentionally impair teaching and learning of Integrated Science, especially to the secondary speaker. In the teaching and learning of science, pupils are encouraged to express their ideas and question evidence in scientific investigations as they develop their concepts in science. Thus, for a learner to understand scientific concepts and express themselves effectively using the concept that learner must have a high level of proficiency in the language used to present the concept. Tan and Tan (2008) and Ferreira (2011) stated that learning in a second language is considered challenging when learners experience difficulty in deducing the meaning of Mathematics 
and Science concept words. The problem of learning Science through a second language is compounded if the science teacher is also not proficient in English (Ong, 2004). Clearly, the use of English language can serve as a barrier that affects pupils' understanding of scientific concepts. This is likely to affect the performance of pupils in Integrated Science. For effective teaching and learning of Integrated Science concepts attention needs to be given to the language used.

Adequate and appropriate use of instructional material ensures effective teaching and learning of science. Adequate instructional materials and strategies give students the chance to use their senses of hearing, smelling, tasting, seeing, and feeling (Opara \& Etukudo, 2014). If instructional materials are inadequate, students are made to read textbooks while the teachers explain the concepts to them instead of the students carrying out activities as suggested by the integrated science curriculum (Azure, 2015). This deprives pupils of taking responsibility for their learning through active construction and reconstruction of their meanings for concepts and phenomena (Borich, 2007; Brass et al., 2003) hence their performance as compared to pupils with adequate facilities (Idiaghe, 2014). The benefits of the use of instructional materials in teaching and learning of science cannot be overemphasized. This is because as pupils become involved in science activities with the materials they understand scientific concepts better and ultimately improve their performance.

The study specifically assessed the limitations of teachers' use of the English language as the medium of instruction and the availability of instructional materials used in the teaching and learning of Integrated Science in rural JHSs in the Effutu Municipality. Rural schools in the Effutu Municipality in the Central Region were chosen because of the consistent poor academic performance of pupils in the Basic Education Certificate Examination (BECE). The BECE uses a nine-point numerical scale in grading candidates with Grade 1, denoting the highest performance and Grade 9 the lowest: Grade 1 (excellent), Grade 2 (very good), Grade 3 (good), Grade 4 (high average), Grade 5 (average), Grade 6 (low average), Grade 7 (low), Grade 8 (lower), and Grade 9 (lowest) (Akyeampong et al., 2000). Reports from the Effutu Municipal Education Office Statistics Department show that 49.3\%, 49.1\%, and $51.2 \%$ of candidates passed science in the BECE conducted in 2014, 2015, and 2016, respectively. In addition, information gathered from the head teachers in the six schools under study indicated that the majority of the candidates who passed science and English language obtained Grades 5 and 6 with very few of them making Grades 1 and 2. This underperformance could be that pupils could not read and understand the questions to answer them properly. This performance comes as no surprise as pupils are not able to express themselves in the English language (Chief Examiners' Report on the BECE, 2017). Furthermore, the 2013 National Education Assessment reports showed that majority of pupils in basic schools cannot read well enough to understand the English they are reading as reported in the daily graphic (February 13, 2014) by Agyeman. In addition, when a candidate is handicapped in reading, such a candidate struggles throughout the course. In fact, many students in West Africa fail in science achievement tests and examination because of poor understanding of the English language, as noted by the West African Secondary School Certificate Examinations Chief examiner's report in science and elective science subjects (WAEC, 2005).

It is, therefore, essential to investigate these challenges confronting Integrated Science teaching and learning so as to strengthen learners' performance in science. The findings of the study would help uncover measures needed to address the challenges and improve the performance of pupils in the BECE in the rural communities in the Effutu Municipality. The following questions guided the study:

1. What instructional materials are available to assist the teaching and learning of Integrated Science in the rural JHSs in the Effutu Municipality?

2. What are the challenges pupils and teachers face with the use of English as a medium of instruction in teaching and learning of Integrated Science in the rural JHSs in the Effutu Municipality?

\section{METHODOLOGY}

The researchers employed a qualitative approach to seek understanding from those involved in the teaching and learning of Integrated Sciences in rural JHSs. Qualitative research focuses on a smaller number of people for gathering more detailed and richer data for generalizations (Cohen et al., 2009; Osuala, 2001). The study was carried out in the Effutu Municipality in the Central Region of Ghana. The Municipality has 16 public JHSs out of which six rural area schools were purposively chosen. The communities in which these schools were located are classified rural. A community is classified as urban or rural based on the classification provided by the Ghana Statistical Service (2002). A community with a population of $<5000$ is classified as a rural community, while a community with population of 5000 or more is classified as urban.

The head teachers of these rural schools and the Integrated Science teachers were then approached for inclusion in this study. A simple random sampling technique was employed to select 30 final-year pupils, five from each sampled school. The final-year pupils were chosen because they would have had more exposure to the use of English language as the medium of instruction and the use of instructional materials in relation to the teaching and learning of Integrated Science. The data were collected through the use of closed-structured interviews with head teachers and science teachers while focus group discussions were used to collect data from the pupils. The discussions were held with five pupils in each school. Data collection was done in the first term of the 2017/2018 academic year from October to November, a period the participants were not occupied with preparation for BECE in June 2018 for JHS year three candidates. Permission was obtained from the Effutu Municipal Director of Education to carry out the study; the 
schools selected were visited at least twice. The first visit was to enable the researchers to interact personally with head teachers, Science teachers and pupils to solicit their participation and to explain the purpose of the study to them. A convenient date and time for both researchers and participants were scheduled for the interview and focused group discussion for each selected school. A 100\% return rate was achieved. Responses from head teachers, teachers, and pupils were noted and summarized with the main findings presented in a tabular form.

\section{RESULTS}

Participants of the study were six head teachers, six teachers comprising $66.7 \%$ male and $33.3 \%$ female. Their ages ranged between 25 and 50 years with teaching experience ranging from 2 to 18 years. All teachers used for the study were not natives of the Effutu Municipality. All teachers were firstdegree holders. Five obtained a Bachelor of Science (Integrated Science Education) degree and one a Bachelor of Education (degree in Basic Education). Thirty pupils (17 girls and 13 boys) were involved in the study with their ages ranges from 14 to 16 years. The rest of the findings of the study are presented along with the pattern of the research questions.

\section{Research Question 1}

What instructional materials are available to assist in the teaching and learning of Integrated Science in rural JHSs in the Effutu Municipality?

This question sought to find out the availability of instructional materials used in the teaching and learning of Integrated Science. Responses from participants are presented in Table 1.

\section{Research Question 2}

What are the challenges pupils and teachers face with the use of English as the medium of instruction in the teaching and learning of Integrated Science in rural JHSs in the Effutu Municipality?

This question sought to identify pupils' and teachers' challenges in the use of English language as a medium of instruction in the teaching and learning of science. Responses from participants are presented in Table 2.

\section{Other Challenges in the Teaching and Learning of Integrated Science}

Some other challenges were raised by respondents in the teaching and learning of Integrated Science. These were pupils' background, parental or guardian support, and time allocated for science teaching. The background of pupils was identified as affecting the teaching and learning of Integrated Science. From the interview, pupils stated that "some of the concept in Integrated Science is not familiar because we have not seen or experienced it, this makes it difficult for us to get the understanding of the concept." Teachers were not in agreement with pupils comments they said "pupils have the mind that science is difficult and as such do not make enough effort to understand the concept being taught no matter how hard I try to explain the concept." Again, one of the head teachers stated:

\author{
Table 1: Participants' responses on the availability of \\ instructional materials
Main findings
Few scientific apparatus and materials; magnifying lenses, stop clock, weighing balance, beakers, funnel, conical flask, volumetric flask, iodine, sodium chloride, ethanol, potassium per magnate.
Availability of textbooks and charts
Teachers improvised materials for practical activities: Coal pot, cooking pots, spoons, plastic plates, napkins, tissue paper

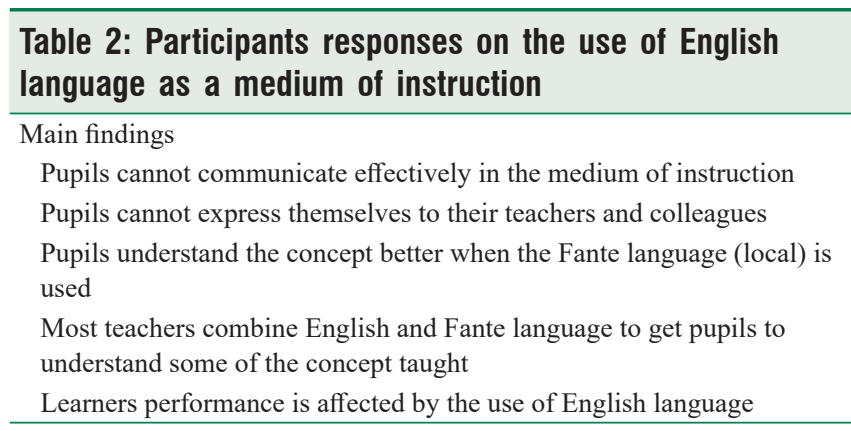

Unfortunately, we find ourselves in a community where poverty is high and most of the people are not enlightened and do not appreciate the importance of education; they prefer their wards to assist them in their fishing business than to be going to school.

Pupils also had similar view "we prefer to assist our relatives especially during fishing season so we can make some money to buy stationaries for school and to pay our school fees and other needs leading to absenteeism on the part of pupils." In addition, parents or guardians could not assist pupils academically since most of them were illiterate as reported by the teachers and head teachers. This was echoed by pupils "my parent (or guardian) cannot help me with my homework because they do not understand the questions since they cannot read and write." It was also noted that time allocated for Integrated Science teaching was inadequate as revealed by respondents. The teachers said "the time allocated for Integrated Science on the timetable is not enough to teach the theory, have practical activities, and assess the pupils; this makes us haste the pupils through the topics." Again, "teachers are unable to cover all topics lined up in the syllabus before pupils take the BECE." These may contribute to pupils' poor performance in the BECE. Pupils also had similar views "we mostly use other teachers' periods when we have science lessons especially, practical lessons." It is then clear that pupils in rural schools face challenges in learning Integrated Science due to their community.

\section{DISCUSSION}

The findings of the study are discussed under various headings reflecting the objectives of the study.

\section{Availability and the use of Instructional Materials}

Effective teaching and learning of Integrated Science require adequate resources. Mudulia (2012) asserted that science 
teaching textbooks, revision books, laboratory chemicals, and equipment should be readily available for effective teaching and learning of science. From the study, all participants noted that there was "no science laboratory or science kit in their school," they also highlighted that for the few apparatus and materials available "we carry them from the head teachers' office to the classroom to demonstrate the scientific concept taught." Due to the inadequacy of the apparatus, Integrated Science lessons were mostly in the lecture format with limited demonstrations. This was explained by a teacher "because we do not have the materials to carry out most practical activities indicated in the textbooks, we mostly explain the concepts to pupils." This does not give the pupils the opportunity to perform the practical activities on their own so as to develop their process skills which were a requirement for pupils at the JHS (CRDD, 2012). Furthermore, the inadequacy of science apparatus makes practical activity difficult to be carried out, as most of the teachers said "we undertake practical activities in the form of demonstration once in a term because we make a lot of sacrifice in terms of providing and improvising materials using monies from our pockets, making carrying out practical activities very challenging." In addition, "we need to cover most of the topics outlined in the Integrated Science teaching syllabus so we use the lecture method mostly because time is limited" was stated by most of the teachers. Hence, the possibility of pupils having hands-on science activities opportunities advocated in the 2012 Integrated Science Teaching Syllabus for JHS is non-existent.

Textbooks and wall charts were identified as regular instructional material used during the teaching and learning of science. This was reiterated by pupils:

We all have a copy of the Integrated Science textbooks, teachers explain the concepts in the textbooks and on the wall charts to us without carrying out practical activities with us. We are also made to memorize all the scientific concepts as well as the procedures of all practical activities in our textbook. This makes learning of Integrated Science very difficult and complex.

The available textbooks and charts are not enough to promote effective teaching and learning of Integrated Science, so most of the concepts are explained for pupils to memorize. This affirms the findings of Azure (2015). Again, the textbooks may outline, describe phenomenon, and show pictures about things and what they would observe in the outlined practical activities. This mode of teaching does not encourage a handson approach to learning for pupils. It also deprives pupils of taking responsibility for their learning through active construction and reconstruction of their meanings for concepts and phenomena (Borich, 2007; Brass et al., 2003). This could explain the poor performance of pupils in science as report in the BECE. This finding agrees with Idiaghe (2014) that pupils in schools with inadequate instructional materials performed poorly as compared with their counterparts in schools with adequate facilities. The availability of variety of instructional materials would afford the teachers the opportunity to use variety of teaching strategies and encourage pupils to find out more on their own thereby stimulating self-learning. It could also create interactions and interest in class and saves the teacher the trouble of explaining at length. Again, it would encourage more pupils to explore and discover knowledge within their environment and make meaningful contributions to existing scientific principles. These would help deepen many pupil's understanding of concepts taught which would then impact positively on their performance.

The use of English Language as a Medium of Instruction The medium of instruction for teaching Integrated Science in JHS is the English Language. Teaching Integrated Science to the individuals whose mother tongue is not English may pose some challenges, which would eventually influence their performance. This is echoed when almost all the pupils noted similar statements along the line "I understand the concepts better when the Fante language is used." Again, "since English language is the accepted language in class, Integrated Science lessons are boring, but when the teacher allows us to speak the Fante language we are able to communicate and make the class exciting." If pupils are not able to express themselves and exchange ideas in science classes, it makes the teaching and learning of integrated science more challenging and unattractive. This may result in pupils losing interest and developing a poor attitude to the learning of Integrated Science. All the teachers confirmed that most of the pupils had challenges with the use of English as medium of instruction, which hindered their interactions in class. They said:

most times I have no choice other than to use both Fante and English to explain the concept to support the understanding of the pupils although Fante is not the first language of all the pupils it is the common local language we all understand.

Ong (2004) observed that the problem was acerbated if the science teachers were not proficient in the English language. The same could be said if teachers had poor proficiency in the Fante language as it would be difficult for teachers to explain effectively some scientific concepts and words used appropriate in the local language (Fante language) to facilitate pupils' understanding. The use of the Fante language could also serve as a barrier for effective teaching and learning of science as well as the use of scientific terms or words by the pupils. This finding agrees with both Tan and Tan (2008) and Ferreira (2011) who observed that learning in a second language is considered challenging when learners experience difficulties in deducing the meaning of Mathematics and Science concept words by the pupils. These could be very demanding for the pupils as they have to struggle through scientific concepts and the medium of instruction, which may negatively affect their performance.

\section{CONCLUSION}

From the findings, it can be concluded that there are inadequate instructional materials used in the teaching and learning of 
Integrated Science in rural JHS in the Effutu Municipality. It was also revealed that the medium of instruction was a hindrance for both teachers and pupils in the teaching and learning of Integrated Science.

\section{Recommendations}

Based on the findings, the following recommendations are made:

1. Effutu Municipality Education Service in collaboration with the University of Education, Winneba should organize in-service training on the improvisation of instructional materials for Integrated Science teachers in rural JHSs. This will help vary their instructional strategies so as to reach the individual pupil in class. The improvised instructional materials would also help pupils to develop scientific concepts on their own as they interact with them.

2. Teachers should develop strategies to increase pupils' vocabulary of science concept words to facilitate pupils' participation during Integrated Science lessons.

3. Pupils should be encouraged to build on their English vocabulary through the reading novels to improve both spoken and written of the English language. This will impact positively on their participation during lessons.

4. More time should be allotted on the teaching timetable to an enabled maximum coverage of outline topics in the Integrated Science syllabus.

5. Parents and guardians should be encouraged to prioritize their wards education.

\section{REFERENCES}

Agyeman, N.K. (2014). Majority of Basic School Pupils Cannot Read-NEA Report, Daily Graphic. Available from: https://www.graphic.com.gh/ news/education/majority-of-basic-school-pupils-cannot-read-neareport.html. [Last accessed on 2019 Jul 10].

Akyeampong, D.A., Asomaning, W.A., Akyeampong, A.K., Mereku, K., Tingbani, L.T., Addo, B., \& Agyemang-Duah, S. (2000). Report of the Committee to review the Basic Education Certificate Examinations (BECE) Grading System. Accra: Curriculum Research and Development Division of the Ghana Education Service.

Anamuah-Mensah, J., Ananga, E.D., Wesbrook, J., \& Kankam, G. (2017). National Teachers'Standards for Ghana-Guidelines. Ghana: Ministry of Education.

Azure, J.A. (2015). Senior High School Students' views on the teaching and learning of integrated science in Ghana. Journal of Science Education and Research, 1(2), 49-61.

Borich, G.D. (2007). Effective Teaching Methods: Research Based Practice. USA: Prentice Hall.

Brass, C., Gunstone, R., \& Fenshman, P. (2003). Quality learning of physics: Conceptions held by high school and university teachers. Research in
Science Education, 33(2), 245-271.

Chief Examiners' Report. (2019). General Resume of the Chief Examiners' Reports on the Basic Education Certificate Examination for School Candidates, 2017. Available from: https://www.thesisexamples. blogspot.com/2018/08/chief-examiners-report-on-bece-2017.html. [Last accessed on 2018 Nov 21].

Cohen, L., Manion, L., \& Morrison, K. (2007). Research Methods in Education. $6^{\text {th }}$ ed. London: Routledge Falmer.

Curriculum Research and Development Division (CRDD). (2012). Teaching Syllabus for Integrated Science (Junior High School). Accra, Ghana: Ghana Education Service.

Ferreira, J.G. (2011). Teaching life sciences to English second language learners: What do teachers do? South African Journal of Education, 31, 102-113.

Fredua-Kwarteng, Y., \& Ahia F. (2005). Ghana Flunks Mathematics and Science: Analysis. Available from: http://www.ghanaweb.com/ GhanaHomePage/NewsArchive/artikel.php?ID=75906. [Last accessed on 2010 Jul 18].

Ghana Statistical Service (GSS). (2002). 2000 Population and Housing Census: Summary Report of Final Results. Accra, Ghana: Ghana Statistical Service.

Hill, H.C., Rowan, B., \& Ball, D.L. (2005). Effects of teachers' mathematical knowledge for teaching on student achievement. American Educational Research Journal, 42, 371-406.

Idiaghe, J.E. (2004). Relationship between Educational Facilities, Teachers' Qualifications, School Location and Academic Performance in Secondary Schools in the Delta State. Unpublished Doctorate Thesis. Abraka: Delta State University.

Ministry of Education (MoE). (2010). Teaching syllabus for Natural Science for Junior High School. Accra, Ghana: Curriculum Research Development Division.

Ministry of Education Science and Sports (MoESS). (2007). Teaching Syllabuses for English Language (Primary 1-4). Accra, Ghana: Curriculum Research Development Division.

Mudulia, A.M. (2012). The relationship between availability of teaching learning resources and performance in secondary school science subjects in Eldoret Municipality, Kenya. Journal of Emerging Trends in Educational Research and Policy Studies, 3(4), 530-536

Ngman-Wara, E.I. (2015). Ghanaian junior high school science teachers' knowledge of contextualised science instruction. Journal of Curriculum and Teaching, 4(1), 174-176.

Ong, S.L. (2004). Preparing preservice teachers to teach science in English. Journal of Education, 4(1), 23-31.

Opara, P.N., \& Etukudo, D.U. (2014). Factor affecting teaching and learning of basic science and technology in primary schools. Journal of Educational Policy and Entrepreneurial Studies, 1(1), 46-58.

Osuala, E.C. (2001). Introduction to Research Methodology. Onitsha: Africana-FEP.

Parker, J. (2004). The synthesis of subject and pedagogy for effective learning and teaching in primary science education. British education Research Journal, 30(6) 819-839.

Tan A.L., \& Tan, S.C. (2008). Authority and transmission versus knowledge building: Dilemma in learning science. In: Lee, Y.J., \& Tan, A.L. (Eds.), Science Education at the Nexus of Theory and Practice. Rotterdam: Sense Publishers. p239-251.

West African Examinations Council (WAEC). (2005). West African Secondary School Certificate Examinations (WASSCE). Chief Examiner's Report. Nigeria: WAEC Press. 